University of Louisville

ThinkIR: The University of Louisville's Institutional Repository

Electronic Theses and Dissertations

1943

\title{
The development of the megagametophyte of Ailanthus altissima.
}

Esther L. Bossung 1912-1994

University of Louisville

Follow this and additional works at: https://ir.library.louisville.edu/etd

Part of the Botany Commons

\section{Recommended Citation}

Bossung, Esther L. 1912-1994, "The development of the megagametophyte of Ailanthus altissima." (1943). Electronic Theses and Dissertations. Paper 1911.

https://doi.org/10.18297/etd/1911

This Master's Thesis is brought to you for free and open access by ThinkIR: The University of Louisville's Institutional Repository. It has been accepted for inclusion in Electronic Theses and Dissertations by an authorized administrator of ThinkIR: The University of Louisville's Institutional Repository. This title appears here courtesy of the author, who has retained all other copyrights. For more information, please contact thinkir@louisville.edu. 


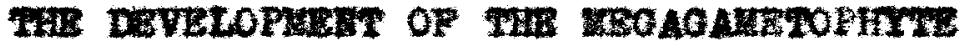

OF AILANTEDS ALTIS:I 


\title{
University of Loulavilie \\ The Development of the regagametophyte \\ or Allanthus Altissima
}

\author{
A Dissertation \\ Subuftted to the Faculty of the \\ Graduate Sohool of the University of Loulavilie
}

In Pertial Fulfillment of the

Requirements for the Degree

of Master of Science

Department of Blology

By

Eather L. Bossung

1943 
Name of student: Eather L. Bosaung

Title of Thesis: The Development of the Uegesemetophyte of Allenthus A1tissima

Thes is Director: Dr.P. A. Daviea

Approved by a Reading Comittee Composed of the Folioning:

Date: September 6, 1943 
Acknom ledgement

In sineerest approciation of the

kindness and generosity or Dr.

P. A. Davies, whose stimulating and

sympathetio direction have mado this

study possible. 
CONTENTS

Chapter

I. Introduction $\ldots \ldots \ldots \ldots \ldots \ldots \ldots \ldots \ldots \ldots$

II. Materiale and Nethods ...............4

III. Description of the Flower Parta ......6 6

IV. Development of the ovule ............12

V. Megasporogenesis and the

Development of the Hogagametophyte .... 18

VI. Summary $\ldots \ldots \ldots \ldots \ldots \ldots \ldots \ldots \ldots \ldots \ldots \ldots \ldots \ldots \ldots, 32$

VII. LI terature c1ted $\ldots \ldots \ldots \ldots \ldots \ldots \ldots \ldots$

VIII. Plater $\ldots \ldots \ldots \ldots \ldots \ldots \ldots \ldots \ldots \ldots \ldots \ldots \ldots \ldots \ldots \ldots 46$ 


\section{IMDEX TO TABLES - PLATES}

Tablo

Page

I. Flowering Perlod ..................... 9

II. Growth of Buds ....................... 10

III. Growth of Fruits ................... II

Plate

Page

I. Early Development of the Orule .......... 48

II. Undifferent1 utod Archesporial cell ..... 50

III. Early Development of the Integument ..... 52

IV. Formetion of Tetrad of Megaspores ....... 54

V. Longitudinal Section of the Entire Ovary. 56

VI. Development of the Chalazal Megaspore .... 58

VII. Two-nucleate Enbryo Sac ................ 60

VIII. Enlargement of Two-nucleate Embryo sac .. 62

IX. Elght-nucleate Megaganatophyte stage .... 64

X. Mature Megagametophyte ................ 66

XI. Enlargement of Mature Megagametophyto ... 68

XII. Formation of the Primary Endosperm Cell . 70 
C H A T R I 


\section{IHTRODUCTION}

A conception of the orderly and logleal procesa of the development of the ovule is of primary importance to the atudent af botang. Descriptions of the construction and organization of the plant body are needed to olve functional aepects of plant development and to trace underiying similarities in form between various plant.

Comparison of the riower parto and atructures oonnected with sexual reproduction is one of the most dependable and most frequently used bees for fudgment as to the relationship of planta. Reprom duet1ve stmatures are nore dependable than vegetative organs as indloators of relationshlps. They ere shorter-11ved and are abjected for shorter perlods to onv1ronmental inmuences. Their relation to the onvironment is not so close and thels struoture Is less $11 k e 1 y$ to vary in response to changes in the environment.

On aceount of this greater atability of reproductive structurea and relatively greater value In ahowing actual relationahipa, morphological studies of the development of flower parte have been of prime importanoe in classification. 
Recent botanfical research indicates a trend of increased interest in the morphological development of plants. Numerous detalled studies of tho early development of the ovale, megasporogenesis and the development of the megagametophyte are recorded in recent botanical ilterature. The greater number of theee studies have been made in the family Leguminosee. No studies conoerning the development of the orule of Allanthus altiss ima have been made. It is the purpose of this study to trace the development of the megagametophyte in Allanthus altiasima. 
C H A P T R R II 
MATERIALS AIDD METHODS

P1stillate panioles of Allenthus altlasima Swinglo wero collected at two day intervals beginning May 26, 1942 through July 22, 1942. These wero collected from meture trees on Poplar Lovel Roed near Loulaville, Kentucky. Slnoe the nowers in a panicle do not open at the same time, varying degrees of developwent were found in each pist1llate paniele.

Flowers were dissected to observe the number and arrangement of flower parts. Measurements of the spread of the petals and the length of the samaras were recorded. The length of the flowering perlod was recorded.

The pantcles were fixed in formalin acetic alcohol, as given by Chamberlin (1932). The buds and flowers were dissected and the five doeply cleft ovarlea dehydrated by the zirkle (1930) mothod and ombedded in paraffin.

Serial sections were cut ten microns in thicknose. They wero atained with gontian violet and mounted in balsam.

Camera-lucida drawings wore made at table leve1. 
C H A TER III 


\section{DESCRIPTION OF FLOWER PARTS}

The groenish-whlt polygamomdloeclous flowers of Allanthus altissima are borne in torminal upright penteles 10 to $20 \mathrm{~cm}$. long. The average number of potential flowers present in a platillate paniclo for three consecutive yoare was 146 flowers. The counts were made at the time the flrst flowers were opening, so all buds were consldered potontial flowers. The flowers in a paniclo do not all open at the ane time. The average perlod from the beginning to the ond of flowering in pletillate panicles was 10 days, fron June 2 through June 12. Table I shows that the average percentage of flowers open June 2 was 20.1; for June 5, 20.0; for June 3, 51.1; for June 10, 53.7 and for June 12, 6.7. Th1s date 18 inoluded as a basis for determining the opening of the first pistillate flowers.

Table II shows the increase in length of the buds from lfay 26 to June 2. The average for 25 bud longths shows a gradual increase in size from $2.61 \mathrm{mom}$. on May 26 to $4.24 \mathrm{~mm}$, on June 2 . The flowers are small and usualiy regular

$\mathbf{I}$

Unpublished data by P. A. Davies 
With Ifve spreading, valvate, greenish-white petals. The average of 500 meesurements of the spread of potels of pietillate flowers was $6.9 \mathrm{~mm}$. The potals are several times longer then the flve imbricated sepals and are Inserted on a ten-lobed flattoned dise. Piatillate flowers have a gynoeolum of rive unt ted carpels. The pistil contains a five-1obed flattened ovary, with a solltary ovule in oach cav1ty. The ovule becomes anetropous as it dovelope. The styles are united, twisted rope-11ke and have elongated spreading stigmas. Ten non-functional etamens are inserted at the base of the disc. The frult, an elongeted samara, hes mombranow, veiny wing and a single, compressed seed is altuated in the middie:

Table III shows the everage length of 25 fruits in panicles collected from June 2 through July 1. The data Indicates en inorease from $2.5 \mathrm{~mm}$ for fruits in panioles collected June 2 to $38.9 \mathrm{~mm}$ for frulte collected July 1. Widely varying degrees of frult development were found in sach panicle.

Ibla*, p. 5 . 
TABLE I. FLOWERINO PERIOD OF AILANTHUS ALTISBIMA

\begin{tabular}{|c|c|c|c|c|c|c|c|c|c|c|c|c|}
\hline Dete & & & \multicolumn{8}{|c|}{ Tumber of buds and flowers per panicle } & 10 & $\begin{array}{l}\text { Por cont } \\
\text { Buds open }\end{array}$ \\
\hline \multirow[t]{2}{*}{ May 30} & Buds & 175 & 108 & 167 & 108 & 114 & 167 & 160 & 161 & 167 & 138 & \multirow[t]{2}{*}{0} \\
\hline & Flowe re & 0 & 0 & 0 & 0 & 0 & 0 & 0 & 0 & 0 & 0 & \\
\hline \multirow[t]{2}{*}{ June 2} & Bude & 164 & 125 & 178 & 157 & 70 & 157 & 196 & 157 & 235 & 102 & \multirow[t]{2}{*}{20.1} \\
\hline & Fl owers & 47 & 22 & 39 & 39 & 16 & 55 & 16 & 0 & 39 & 30 & \\
\hline \multirow[t]{2}{*}{ June 5} & Buda & 152 & 221 & 233 & 132 & 178 & 104 & 60 & 72 & 160 & 152 & \multirow[t]{2}{*}{20,0} \\
\hline & Flowex: & 82 & 80 & 16 & 8 & 0 & 28 & B & 20 & 40 & 40 & \\
\hline \multirow[t]{2}{*}{ June 8} & Bade & 138 & 167 & 161 & 150 & 167 & 114 & 108 & 167 & 108 & 175 & \multirow[t]{2}{*}{51.1} \\
\hline & Flowera & 78 & 72 & 102 & 54 & 114 & 78 & 72 & $n$ & 42 & 60 & \\
\hline \multirow[t]{2}{*}{ June 10} & mude & 116 & 136 & 104 & 168 & 274 & 108 & 188 & 140 & 187 & 210 & \multirow[t]{2}{*}{53.7} \\
\hline & Flowere & 0 & 52 & 97 & 120 & 84 & 70 & 125 & 128 & 58 & 67 & \\
\hline \multirow[t]{2}{*}{ June 12} & Buds & 120 & 106 & 134 & 197 & 106 & 276 & 268 & 127 & 134 & 98 & \multirow[t]{2}{*}{6.7} \\
\hline & Howers & 0 & 0 & 7 & 7 & 21 & 28 & 21 & 7 & 7 & 0 & \\
\hline \multirow[t]{2}{*}{ June 14} & Buda & 110 & 148 & 187 & 123 & 105 & 168 & 174 & 116 & 194 & 136 & \multirow[t]{2}{*}{0} \\
\hline & Flowera & 0 & 0 & 0 & 0 & 0 & 0 & 0 & 0 & 0 & 0 & \\
\hline
\end{tabular}


TABLB II. GROWTH OF BUDS

\begin{tabular}{|c|c|c|c|}
\hline \multicolumn{4}{|c|}{ Weasurements of Buds in in. } \\
\hline Mey 26 & May 28 & May 30 & June 2 \\
\hline 2.50mm. & $3.00 \mathrm{~mm}$ & $3.50 \mathrm{~mm}$ & $4.25 \mathrm{~mm}$ \\
\hline 2.25 & 2.90 & 3.25 & 5.00 \\
\hline 3.00 & 2.95 & 2.00 & 4.25 \\
\hline 2.75 & 2.85 & 3.60 & 4.75 \\
\hline 3.10 & 3.30 & 3.75 & 4.05 \\
\hline 2.90 & 2.85 & 4.00 & 4.00 \\
\hline 2.80 & 2.80 & 3.95 & 4.30 \\
\hline 2.75 & $3: 10$ & 3.50 & 4.40 \\
\hline 2.80 & 2.85 & 3.55 & 4.50 \\
\hline 2.75 & 2.75 & 2.50 & $4 \cdot 10$ \\
\hline 2.40 & 2.85 & 3.75 & 4.25 \\
\hline 2.50 & 2.95 & 3.25 & 4.05 \\
\hline 2.60 & 2.75 & 3.15 & 3.75 \\
\hline 2.50 & 2.75 & 2.75 & 4.35 \\
\hline 2.00 & 2.80 & 3.05 & 4.75 \\
\hline 2.60 & 2.50 & 3.25 & 4.05 \\
\hline 2.05 & 2.55 & 4.00 & 4.80 \\
\hline 2.25 & 2.90 & 3.75 & 3.60 \\
\hline 3.00 & 2.90 & 3.80 & 3.25 \\
\hline 2.56 & 2.95 & 3.35 & 4.50 \\
\hline 2.85 & 2.00 & 3.25 & 4.55 \\
\hline 2.45 & 2.75 & 3.60 & 4.25 \\
\hline 2.90 & 2.70 & 3.00 & 4.50 \\
\hline 2.80 & 2.90 & 3.20 & 4.55 \\
\hline 2.50 & 2.80 & 3.35 & 3.50 \\
\hline $2.62 \mathrm{~mm}$ & $2.81 \mathrm{~mm}$ & $3.28 \mathrm{~mm}$ & 4.24m \\
\hline
\end{tabular}


TABTS III.

GROTTE OF FRUITS OF AILAUTHUS ALTISBTHA

\begin{tabular}{|c|c|c|c|c|c|c|c|c|c|c|c|c|}
\hline & & & & & & & & & & & & \\
\hline & $\mathbf{z}$ & 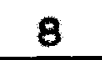 & & 12 & 14 & 16 & 18 & 20 & 25 & 26 & 28 & nus \\
\hline & & & & & 0 & & 1 & 3 & .5 & 0 & 21.0 & 47,0 \\
\hline & & & & & 0 & & 8 & 18.5 & 3.0 & 30.5 & 3.0 & \\
\hline & & & & & & & 0 & .0 & 0 & .0 & & \\
\hline & & & & & 8.0 & 0 & .0 & 18.0 & 7.0 & 9.0 & .0 & \\
\hline & & & & & .0 & .5 & .0 & 2.5 & 5.0 & 5 & 0 & \\
\hline & & & & & .0 & .0 & $: 5$ & 4.0 & 5.0 & 5 & 5 & \\
\hline & & & & & 8.5 & .5 & .0 & 3.5 & 3.0 & 0 & .0 & \\
\hline & & & & & 8.0 & .0 & 5 & .0 & 5 & .0 & 5 & \\
\hline & & & & & 9.0 & 5 & .0 & .0 & 5.5 & 0 & .0 & \\
\hline & & & & & .5 & .5 & .5 & .0 & .0 & 0 & 0 & \\
\hline & & & & & 6.5 & 0 & 0 & .0 & 5 & 6.0 & 0 & \\
\hline & & & & & 0.0 & 5 & 7.0 & 0 & 7.0 & 0 & 0 & \\
\hline & & & & & 9.0 & 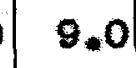 & 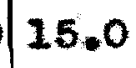 & 6 & 0 & 0 & 7.0 & \\
\hline & & & & & 8.0 & 0 & 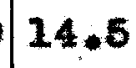 & .0 & .0 & 0 & 5 & \\
\hline & & & & & 5 & & 5 & 0 & 8.5 & .0 & 0 & 6.1 \\
\hline & & & & & .5 & & .0 & .0 & .5 & 2.0 & 7.0 & 8.1 \\
\hline & & & & & 8.5 & & .0 & .5 & 18.0 & 8.0 & 7.0 & 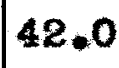 \\
\hline & & & & & 8.0 & 5 & .0 & 13.0 & 2.0 & 8.0 & 30.0 & 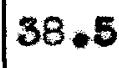 \\
\hline & & & & & 8.0 & 0 & 2.0 & 18.0 & 21.5 & 24.0 & 26.5 & \\
\hline & & & & & 7.5 & 3 & 6.0 & 17.0 & 0.0 & 22.0 & 27.0 & \\
\hline-1 & & & & 0 & 9.5 & & .5 & 515.0 & 14.0 & 23.0 & 27.0 & 5.6 \\
\hline & 3 & 4 & .0 & 5.5 & 10.5 & 10.5 & 10.0 & 11,0 & 20.5 & 28.0 & 24.0 & $*$ \\
\hline & & & .0 & & 8.0 & 6.0 & 11.0 & 12.0 & 16.0 & 28,0 & 26.0 & \pm 0 \\
\hline 7 & 3.0 & 5 & 6.5 & & 8.0 & 8.0 & 9.5 & 515.0 & 17.5 & 21.0 & 28.5 & $\infty$ \\
\hline & 8 & & 8 & & 3.3 & 2 & -8 & 3 & .9 & 5.9 & .4 & \\
\hline
\end{tabular}


O H A P T I IV 
A solltary ovule ariass in each carpel of the five-lobed flattened ovary. The young ovule 1s Inttiated by the multiplication of the hypodexen eelz: of the plecenta (Plater I and II). As the rounded protuberanee of undifferentlated cella pushes out into the carpel of the ovary and continus to develop. cell divialon becomes more active on one side with the result that the ovile begins to bend toward the apex of the ovary (Plate III). Velnatein (1926). In Phaseolus found almiles ourvature of the orules toward the apex of the ovary. The curvature of the ofule begins before the ovule touohes the corsal wall of the ovary. D. C. Cooper (1985, 1942), in Hel1lotus albe and Lobelle cardinalis, and 0.0 . Cooper (1941), In Phrrma leptostechre found that the continued growth and elongation of the funteylus and moro rapld alvision of the oells In the chalazal region of the ovule opposite the placenta enuse the ovule to curve Imward tomard the base of the ovile. Reeves (1930). In his study of the ovulo of yodienge sativa, conoluded that the direction of this curvature may bo determined wechanieally by the growth of the carpel. 
He found that the young ovule of Mediosgo sativa was orthotropous unt11 it cane in contact with the corsel wall of the ovary and then it began to bend, usually toward the base. Reeves obeerved that occastonally. owing to the pressure exerted by the carpel wall, one of the upper oviles curved toward the stylar ond. Ho sharply differentiated archesporial cell could be found (Plates I. II, and III). It was aifrieult to determine whether a cell was sporogenous unt1l after the archesporial cell divided. The aame situation was found by Reeves (1930), In Medicago sative. A single archesporial cell which cen easily be 1dentified by 1 ts dense oytoplasm and large nucleus 1s the usual case in anglosperms. Mast observers of the Leguminosee have found alferentiated archesporial cell. 0.0 . Cooper $(1941,1942 a, 1942 b)$, in Phrrma leptostachra, Iobelie cardinalis, and Plantage lenoeolete found that an apical hypodermal coll was early differentiated as a primary arebesporial cell. He found that this cell had denser eytoplasm and a somewhat larger nuelous than the romaining cells of the ovary.

Cases of multiple axchesporium have been reported by Strasburger (1880), in Rosa, Chamberlain 
(1897), in Salix, Conrad (1900), in guereus, Hurbeok (1901), in Alchomilie, Lloyd (1902), in Callipeltis. Martin (1914), in Trifolium and Modloaso sative, Roeves (1930), in Medicago sativa and D. C. Cooper (1935), in Medicago. In Medicago gativa, Martin (1914). reported that the number of archosporiel cells ranged froat one to six and that more than one usually occurs. Martin found two to four rows of megaspores in the same nucellus and found that of ton more than one megaspore starta to form an embryo sac, but not more than one matures.

As the ovile contlnues to develop the cells of the nucellus become aligned or organized about the potential archesporial cell, which is not alfferontlated at this oarly stage of development (Plate III).

An inner integunent, uswally of twe layers of cells, except at the base where it cocastonelly had three layers of cells, develops as a meristomatio outgrowth from the ohalazal cells below the potentlal arehesporial cell. It grows upward about the apex of the nucellus, As the integument forms, there is more rapid gromth of the ovile on the alde aray from the inain axis. As growth continues, the ovule bends upward and toward the epex of the ovary (Plates III and v). 
Leter, the outer integument, wavalig of three lagers of colls. develops from the nueellve at a level Just below the inner integument. The outer integuinent grows more raplaly on that alde of the ovule away from the placenta and shows little devalopment on the side toward the plecenta (Plate IV).

the two layera of the inner integument grow moro rapidy then the outer integunent, surround the ovule and beoome more massive in the mloropylar region. A similar development of the imer integunent was found by D. C. Cooper (1040), In Portulaea Oleracoa and Anderson (1927). In Poe pratensis and Poa compressa. The outer integument never reaches bejond the level of the apex of the nucellus. This conattion is 11ke that found by D. C. Cooper (1940), in Portulaca olereces. In whioh he found that the outor integument arose as a ristematic outgrowth of the epldermis of the ovule just basal to that of the inner integumant. The outer integument grow more slowiy: so that it nover reached a point whe re its apex took any part in the formation of the mloropylo. Contrary to this type of development of the integuments, D. C. Cooper (1953), In yelllotus, deseribed an outer integument whtch grew more rapldiy than the inmer and bocame massive at the region of the mieropyle. The inner integunent 
was only two layers in thlolnese and grew over the apical end of the embryo sac so as to leave a very short inner portion of the mieropyle.

The curvature of the orule in Mllanthus continus until the longltudinal axis is approximately parallel with that of the ovary wall to which it is attached. The ovulo becomes typlcally anatropous by the tiwe the ombryo acc is mature (PIate V). Similar curvature of the ovule ia deseribed by 0.0 . Cooper (1942a, 1948b), in Lobelle cardinalia and Plentago lanceoleta.

The main vascular atrand extends into the base of the funioulus. A group of mitritive cells having very dense eytoplasmie content is found about the ohalaral ond of the doveloping mogagametophy to (Platea VII, VIII and XI). 
C I A P R V 


\section{MEGASPOROCERESIS AID THE DEVELOPMEAT \\ OF THE MEGAGAMETOPHYTE}

The archesporial coll which is doeply ombodded In the nucellus functions as the megaspore mother cell, increases in size and through two divisicns Elves rise to a linear tetrad of maspores (Plates IV and VI).

In Hedicage sative, Rooves (1930), found that the archeaporial cell ald not directly funotion as the megaspore mother cell. It flrst divided and gave rise to a primary parletal cell and a primary oporom genous oell. He found that tranverse divisions of the parletal oell occurred and gave $M$ se to the three parletal layers, the cells of whieh might divide again. As a result of this procedure, the sporam genous tis aue was deeply embedded. Also he found thet the primery aporogenous cell was canspleuous because of its groater size end its onlarged nuclous. Reoves found that the primery sporogenous cell doveloped directly into the megespore mother oell whout alviding again and by two melotio divialon gave rise to tetrad of megapores. While a linear row of four megaspores is the usual case in the Leguminoseg, variation in 
the number of wegaspores and their arrangement have been observed. Culgnerd (1881), noted the formation of only three in Pheseolus multirlorus and in Medicago arbores. Woinstein (1926), found the presence of three to be typleal of Phaseolus vulgaris. Nelnstein bolleved this to be brought about as the result of an abortive homotyple alvision of the mleropylar cell.

Reoves (1930), In Yedicase sativa, found

Instead of an axial row of four spores, resulting from two horizontal molotio diviolons, as is typioal, the first diviaion of the megaspore mother cell is at right engles to the long axis of the meollus and the plane of the second division sometimes longltudinal. The latter condition was found oceasionally in the terminal momber of the diad. Mottier (1895), in Ranunoulvs and Baranov (1926), in Drtmops is maculata, also discovored this umusual type of totrad arrangemont. Duncamp (1902) roported vartous groupings of mogaspores in tetrads of Fatala japoniea.

Young (1905), in Helllotus alba, roported that the megaspore mother cell developed into the embryo sac without first undergoing tetrad division. Coo and Martin (1920), in their investigation of Yelilotus albe, showed that first division of the megespore mother cell did occur and that it resulted 
In the formation of two daughter colls with the innor megespore the one that persists.

Reeves (1930), In Eodicago gativa, hes shown that two or three tetrads are often found, but that only single megaspore has over been found to develop Into a mature embryo sac. In extreme cases, Reevea found that the chalazal megaspore of as many as thres tetrads persist and undergo first stages of development. but that two of these megaspores disappear about the tIme of the two-nucleate stage.

In Allanthus altissime. the chalazal spore is the largest of the four megaspores. This chalazal spore alone develops into the embryo sac and the other megespores disintegrate (Plates VI and VII). This condition has been noted by Martin (1914), Roeves (1930), G. O. Cooper (1942), and D. C. Cooper (1940), in various spectes studied. Thoir studies have shom that the chalazal megarpore of the row of three or four became the functional ombryo sac mother cell and that the other spores disintegrated. Onlike this type of development, Gulgnard (1881) in Hodicege arboreg, found the 111y type of embryo sac development in whioh all four megaspore muclel participate in the formation of the embryo sac. Barly investigation of Modicage and cloaely 
related genera of Leguminosae Indicated that megesporogenesis proceeded as in Lillum and all four megaspores function. Herail (1889) in Hediogse arborea and Young (1905) in Melilotus albe were in agreement with Guignard.

Hore recent investigations by Martin (1914)

in Medicago set1va and Viela emerioana, Coo and Martin (1920) in Melllotus alba, Reeves (1930) and D. C. Cooper (1935) In redicago sativa have roported that the proess is the same as that usually found In the dicotyledons in which one of the megaspores only is functional while the other three disintegrate. Shattuok (1805) hes reported that the Lilium or Adoxa type of development oecurs in the majority of cases in Dlmus amerlcana. Stenar (1927) described a modification of the Adoxa type in Cagea. In which the megaspore mother cell undergoes two divialons. forming a linear row of four megaspore nucle1, without the intervention of cell walls. All four nuclel divide again, forming a typicel olght-nucleate megagametophyte or only the three nuclel nearest the mieropyle divide and the chalazal nucleus degenerates. Dahlgren (1916) In Armerla and Statice, Haupt (1934) In Plumbego capena1a and Walker (1938) in Ulmua fulva have reported that all four megaspore nuelel onter 
into the development of the mogagamotophyte.

In Allanthus altigsima, the megaspore toward the chalazal ond becomes the functional megaspore (Plato IV). Varlations as to the position of the functional megaspore have been observed. Oulgnard (1881) found that the third megaspore from the mieropylar ond of the tetred functions in several species of Acacia and Saxton (1907) found a similar situation in Cassie tomentose. In several ovules of Poa aretens 28 and Poa compressa, Anderson (1927) found that the outermost megespore developed and formed the ombryo sac.

The persisting chalazal megaspore in Allanthus Atisalma incroases in size and its nucleus dividos int totically in the typioal way (Plates IV and VI). The two nuclel migrate epart and 110 in a poripheral layer of cytoplasm in the micropylar and chalazal ends of the cell (Plates VII and VIII). Before these daughter nuelel divide agaln, the embryo sac becomes greatly elongated and a large vacuole occuples the mid-portion of the cell. The increase in alameter or this oell is sonewhat greater in the aplcal portion of the embryo sac (Plate XI).

As rosult of two further aivisions, typlcal elght-nueleate megaganotophyto is formed (Plates IX 
and $X I$ ). The nuelel in the ohalazal ond bocome, separated from the romainder of the embryo sao and each 11as in an individual mass of cytoplasm, forming three uninucleate antipodal cells. The three nuelel at the micropylar end, two synergids and the ege nuc10us, become the egg apparatus. The ogg nucleus is larger than the nuelet of the symerglds and lies in - mass of cytoplasm within the ombryo sae. The two nuclei dovold of a liniting membrane beoome polar nuelel. One of these from the chalaxal and one from the micropylar end of the cell migrate to the center of the cell and 110 in elose contact to each other (Plates $X$ and $X I$ ).

Quignard (1881) made the earliest detalled study of the ombryo secs of a number of the leguminoase. More recent studies by Reoves (1930) in yodicago, D. C. Cooper $(1935,1938,1940)$ in Yodicago. Plaum sativum, and Portulace oleracee and by G. 0. Cooper (1942a, 1942b) in Lobelie oerdinalla and in Plantege lanceolata roport the formation of typical 1ght-nuoleate sevon-cellod mogagametophytes.

Varlations from the typloal formation of three, uninucleate antipodal cells in ombryo sacs have been reported. Johannsen's work (1984) on Hordeum showed an increes in the number to thirty-3ix 
or more antipodals before fortilization and disorgenlzation of these cells with the begiming of endosperm devel opment. Koomiake (1896) in Trit1cum and Cannon (2900) in Avena fatue found a simllar ineroase in the number of antipodals. Afzelius (1924) in his study of senocio found the entipodals of the forms he examined to be elther binueleate or multinucleate. He atated that in ame instances antipodals may divide so that instead of having thres antipodels a largo number may be present. Reeves (1930) in Medicago setiva found that occasionally only ono nuclear div1sion occurred in the chalasel end and instod of eight nuelel were formed in the embryo sac. Falkor (1938) in glmus fulve stated that occasionally four entipodels were present.

The ege apperatus of Allanthus altissima Is similar to that descrived by Reeves (1930) in Medicage sativa, Walker (1938) in Ulmus fulva, D. C. Cooper (1940) in Portulace, and $G$. O. Cooper (1942a) In Lobelia cerdinalia. In that the egg cell is the largest of the throe cells and has much larger nucleus than the synergids which olongate and extend toward the micropyle.

The two polar nuclel in Allanthus fuse shortly after the formation of the megagametophyte before 
fertilization to forn a primary endosperm nucleus (Plate XII).

D. C. Cooper $(1933,1935)$ in Melilotus and Portulaca, Walker (1938) in Ulmus, and G. 0. Cooper (1942a) in Lobelia found that the polar nuclel fueed to form the primary endospern nuclous before fert111zation.

Mendes (1941) in Coffen arabica reported that the embryo sac ready for fertilization may show the polar nuele1 fused or separate. Fusion aeemed to be accelerated by polination. When pollination falled, he found that fusion did not occur but the ombryo sac remalned intact for a variable length of time.

Reeves (1930) in Modicago sativa stated that the polar nuclel did not completely unite until the time of fertilization. He observed atages in which the polax muclei had bogun to fuse before fertilization. Reoves bolleved this pertial fusion a result of delajed fertilization. D. C. Cooper (1935) in Medicago and 0.0 . Cooper (1938) in Plsum found that the polar nuclel united at the time of fortilization. In Allanthus altiasima, the embryo sac just prior to fertilization consists of the ogg cell, the primary ondosperm cell and threo antipodel cells 
which have soperated from the remainder of the embryo sec. The synerglas disintegrate early (Plate XII).

Woinstein (1926) found that both the ant1podals and synerglds of Phaseolus vulgarls disintegrated early and that the time of fortilization the embryo sac consists of but two cells, the oge and the primary ondosperm coll.

In species that ha been examined, the timo at which the antipodals dis Integrate varles groatly. Unlike the condition found in Mlenthus, Reeves (1930) in Hedicaze, D. C. Cooper (1933, 1940) in Mel1lotus and Portulace and G. O. Cooper (1941) in Phryea found that the entipodals disappoared very early before fertilization. Andersen (2927) in Poe pratensise and Poe compresse hes shown that the Gramineae are consplcuous for their strongly developed antipodals. The entipodals wore found to increase in size in comparison to the oge and each contained a very large nucleus with several nucleolf. Ho found that the three very large antipodal colls porsibtad until late in ondosperm formation, when they ware finally crowded off to cne side, digezted and absorbed by the growing ondosperm. 
Smal (1919) in his sudy of the compositae rocorded that the chalazal antipodal may divide to form as many as four cells, each having one or more mucle1. Th1s longated structure was spoken of as an ageresalve haustorium. G. O. Cooper (1942a) reports that the antipodals of Lobolie cardinalis porsis tod, became onlarged and functioned as houstoria, and algested the cells of the nucellus.

Unlike the condition found in Mlanthue altiasima in which the aynergids disintegrate hortly after the formation of the mature megagametophyte, D. C. Cooper (1933) in Mel1lotus found that the synergids persisted until an embryo of some size was formed. The synergids wore also found to persist after fertilleation by G. O. Cooper (1941, 1942a, 1942b) in Phryma, Lobel1a and Plantago. Mendes (1941) In coffea arables atated that the synergids disappeared at the pessace of the pollen tube over the synergids.

The mature megagametophyte is aurrounded by several layers of cells of the nucellus. The adjacent nucollar colls bocome olongatod and are digested and absorbed by the ombrye sac (Plates $X$ and $X I$ ). Reoves (1930) in Modioggo sativa, D. C. Cooper (1935) In Medicago sativa, and $G$. 0. Cooper (1942a, 
1942b) In Lobelia cardinalis and Plantago lanceolate. observed that the nucellus at the micropylar ond disappoared and the embryo sac came in contect with the integuments. The integument containod tho reserve food. The only place in which the nucellus remained in contact with the megaganetophyte was at the ant1podal and.

In Mlanthus, the large nutritive cella of the nucellus at the chalasal end of the ombryo sac have dense cytoplasmio content and largo nucle1. They persist throughout the development of the megagametophyte (Plates $X, X I$, and XII).

Reoves (1930) found that the nutritive material for the embryo sac was derlved chlefly from the digestion and absorption of the adjacent nueollar cells, and that partiy speciallzed cells also served In the conduction of food to the ombryo sac. These cells which have boen described by Ernst (1910) in Tulipe gesneriane and by him termod "Leitzelien" were of striking apporance and extended into the chalazal end of the ombryo sac. By the time the. fomale gametophyte was mature, Reeves found that vessels could be traced from the base of the funtculus to the "Leitzelien".

In Allanthus altiasima there were no specialized 
cells for the conduction of food froa the vescular strand in the fumiculus to the chalaxal ond of the fomale gametophyto. 
C H A T R VI 


\section{SUDAARI}

The greenish-whl te polygamo-dioeclous flowers of Allanthua altissime are borne in upright paniclea. widely varying degrees of fruit development are found in each paniele.

The flowers are small, usually regular with flve apreading valvate greenish-white petals inserted on a ten-lobed llattened disc, five imbricated sepals and ton non-functional stameno inserted at the base of the diso.

The fruit, an longated samara, has a membranous, veing wing and singlo, compressed seed is stuated in the middio.

Pistillat flowers have a gynoecium of five united carpols. Bach corpel of the five-loculed pistil contains solitary ovule which is anatropous et maturity.

The archesporial cell which is deeply ombedded In the nucellus is not sharply differentiated and could not be distingulshod until after it divided.

An Inner integument of two layers of cells develops more rapidy than the outer integunent of three layers, surrounds the ovule, and becomes massive in the micropyler region. The outer integument never reaches beyond a level even with the apex of the nucellus. 
The main vaseular atrand extends into the base of the funioulus. Iutritive cells of donse cytoplasmic content are found about the chalazsl end of the mogaganotophyte.

A Ilnear row of four mogaspores is formed as result of two divialons of the archesporial cell which functions as the megaspore mother cell. The chalazal megaspore of the tetrad is the largest and becomes the functional embryo sao mother cell. The three micropylar megaspores diafntegrate.

A typleal elght-nucleate seven-celled megagametophyte is formed which consists of three antipodel cells at the chelazal ond three larger colls, the 08 apparatus, at the micropylar ond; and a largo central two-nucleate endosperm cell. The polar nuolel fuse shortis after the formation of the megagame tophyte.

The synergids extend into the micropylar ond of the embryo sac and disintegrate before the antipodals at about the tim the primary endosperm oell is formed.

The diametar of the megagame to hiyte beccues greatly extended during the course of development from the first nuclear aivision onward. The adjacent cells of the nucellus become flattened and elongated. 
They disintegrate as the negagame tophyte enlarges.

The micropylar end of the megagametophyte at maturity is surrounded by severel layers of the nucellus. 
C II A P TE R VII 


\section{IITERATURE CITED}

Afzelius, K. 1924 mbryologische und zytologlsche Studien in Senecio und verwandten Galtungen. Act1, hort1. Berlana. $8 \mathrm{Nr}$.

7. Quoted by Cooper, G. 0. 1938

Cytologlcal Investigations of Plaum sattrua. Bot. Gaz. vol. 99, pp. 584-591.

Andersen, A. M. 1927 Dovelopment of the fomale gametophyte and caryopsis of Poa pretensis and Poa compresse. Jour. AËr. Res. vol. 34, pp. 1001-1018.

Baranov, P. 1926 Cytolog1sche und embryolog1scho Untersuchungen on Drimope is maculata. Ze1tchr. Zellforsch. Mkr. Anat. 3: 131-148. Quoted by Reeves, R. G. 1930 Development of ovule and embryo sac of alfalfa. Amer. Jour. Bot. vol. 17, pp. $239-246$.

Cannon, W. A. 1900 A morphologiegl study of the flower and embryo of the wild oat. Avena fatua L. Calif. Acad. Sc1. Proc. (3) 1: pp. 329-364. Quoted by Andersen, A. M. 1927 Development of the femalo 
gametophyte and caryops is of Poa pratonals and Por compressa. Jour. Agr. Res. vol. 34. pp. 1001-1018.

Chamberlin, C.J. 1897 Contribution to the Iffe history of Sallx. Bot. Gaz. vol. 23, pp. 147-179. Quoted by Reeves, R. G. 1930 Development of ovule and embryo sac of alfalfa. Amer. Jour. Bot, vol. 17. pp. 239-246.

Chamberiln, C. J. 1932 Mothods in plant histology. 5th od. Chleago pp. 107-109.

Coe, H. S., and J. N. Martin 1820 sweet clover seod. U. S. Dept. Agr. Bull. 844. Quoted by Reeves, R. G. 1930 Development of ovule and embryo sac of alfalfa. Amor. Jour. Bot. vol. 17, pp. 239-246.

Conrad, A. H. 1900 A contribution to the ilfo history of Quercus. Bot. Gaz, vol. 29, pp. 408-418. Quoted by Regves, R. G. 1930 Development of ovule and embryo sac of alfalfa. Amor. Jour. Bot. vol. 17, pp. $239-246$. 
Cooper, D. C. 1933 Macrosporogenesis end embryology of Melilotus. Bot. Gaz. vol. 95, pp. $143-155$.

Cooper, D. C. 1935 Mecrosporogenesis and embryology of Medioagc. Jour. Agr. Res. v01. 51, pp. $471-477$.

1938 Embryology of Plsum sativum. Bot. Gax. vol. 100, pp. 123-132.

1940 Macrosporogenesis and embryology of Portulaca ole racea. Amer. Jour. Bot. vol. 22, pp. 453-459.

Cooper. G. 0. 1938 Cytolog10al investigations of P1sum sativum. Bot. Gaz. vol. 99, pp. $584-591$.

1941 Macrosporogenesis and the development of the soed of Phryma leptostachra. Amer. Jour. Bot. vol. 28, pp. 755-761.

1942 a Mlcrosporogenesis and development of seod in Lobelia cardinalis. Bot. Gaz. vol. 104, pp. 72-81.

$1942 \mathrm{~b}$ Development of the ovule and 
formation of the soed in Plantage lance-

lata. Amer. Jour. Bot. vol. 29, pp. $577-581$.

Dahlgren, K. V. 0. 1916 zytologische und ambryologlsche studion uber die Rethen Primulales und Plumbaginales. $\mathrm{Kgl}$. Svenska Vetensk. Akad. Handl, vol, $56, \mathrm{Nr}, 4$.

Duncamp, L. 1902 Recherches sur I'embryogenle des Arallaceos. Ann. Sc1. Nat. Bot. VIII 15. pp. 311-402, Quoted by Reeves, R. G. 1930 Development of ovule and embryo sac of alfalfa. Amer. Jour. Bot, vol. 17, pp. $239-246$.

Ernst, A. 1901 Beltrage zur Konntniss der Entwloklung des Embryosackes und des Embryo (Polembryonie) von Tulipe gesneriana L. Flora 88 37-77. Quoted by Anderson, A. M. 1927 Development of the female gametophyte and caryopsia of Poa pratensis and Poa compresse. Jour. Agr. Res. vol. 34, pp. 1001-1018.

Gulgnerd, L. 1881 Sur Liorigine Da Sac Embryonnal re Bt Le Role Des intipodes. Bull. Soe. Bot. 
Franoe, vol. 28, pp. 197-201. Quoted by Cooper, D. C. 1935 Macrosporogenesis and embryology of Medicago. Jour. Agr. Res. vol. 51, pp. 471-477.

1881 Recherches D' Embryogenle Vegetale Comparea' Iar Memolre Laguminousos. Ann. Sc1. Nat. Bot. (6) vol, 12, pp. 5-166. Quoted by Cooper, D. C. 1935 Mecrosporogenesis and embryology of Medicago. Jour. Agr. Res. vol. 51, pp. 471-477.

Haupt, A. W. 1834 Ovule and embryo sac of Plumbage capens1s. Bot. Gaz. vol. 95, pp. 649659. Quoted by Walker, R. I. 1938 Hacrosporegenesis and embryo development In Ulmus fulva. Bot. Gaz. vol. 99. pp. $592-598$.

Hera11, J. 1889 organes roproducteurs et formation de I'oeuf chez lea Phanerogames. Parla pp. S0. Quoted by Reeves, R. G. 1930 Development of orule and embryo sac of alfalfa. Amer. Jour. Bot. vol. 17, pp. 239-246. Quoted by Cooper, D. C. 1935 Macrosporogenes is and embryology 
of Medicago, Jour. Agr. Res, vel. 51, pp * $471-477$.

Johennsen, w. 1884 Developpoment et constitution De L. Endosperme De I, Orge. Compt. Rend. Lab. Carlsberg 2: 103-133. Quoted by Andersen, A. M. 1927 Development of the female gametophyte and caryopsis of Pow pratensis and Poa compressa. Jour. Agr. Res.vol. 34, pp. 1001-1018.

Jonsson, B. 1883 Polyembronl hos Trifoll um pratense L. Bot. Hotiser. 134-137. Quoted by Andersen, A. H. 1927 Development of the fomale ganetophyte and caryopsis of Poa pratensis and Poa compressa. Jour. Agr. Ras. vol. 34. pp* 1001-1018.

Koernfeke, M. 1896 Untersuchungen Uber Die Entstohung Und Entwieklung Der Sexualorgene Von Triticum. Mit Besonderer Beruckel chtigung Der Fernthellungen. Verhandl. Haturhist. Vor Prouss. Rhe Inlande 53: 149-185. Quoted by Andersen, A. M. 1927 Dovelopmont of the remale gametophyte and caryopsis of Pon pretengis and Poe compresse. Jour. ABr. Rea. vol. 34, pp. 1001-1018. 
Lloyd, F. E. 1902 The comparative embryology of the Rabiaceae. Men. Terrey, Bot. Club. vol. 8, pp. 27-112. Quoted by Reeves, R. G. 1930 Development of ovule and embryo sac of alfalfa. Amer. Jour. Bot. vol. 17. pp. 239-246.

Martin, J. H. 1914 Comparative morphology of some Isguminosee. Bot. Gaz, vol, 58, pp. 154167.

Mondes, A. J. T. 1941 Cytological observations in Coffea. VI. Embryo and ondomperm development in Coffoa arabica I. Amer. Jour. Bot. vol. 28, pp. 784-789.

Mottier, D. M. 1895 Contributions to the embryology of the Renunculaceae. Bot. Gaz. vol. 20, pp. 241-248. Quoted by Reeves, R. G. 1930 Development of ovule and embryo sac of alfalfa. Amer. Jour. Bot. vol. 17. pp. 239-246.

Nurbeck, S. 1901 Parthonogenetische Embryobllaung In der Gattung Alohemilia. Bot. Zelt. 59 129. Quoted by Reeves, R. O. 1930 
Development of ovule and embryo sac of alfalfa. Amer. Jour. Bot. vol. 17, pp. 239-246.

Reeves, R. G. 1930 Development of ovule and embryo aac of alfalfa. Amer. Jour. Bot. vol. 17. pp. 239-246.

Saxton, W. T. 1907 on the development of the ovule and ambryo sac of Cassia tomentosa. Trans. So. Afrtce Ph11. Soc. vol, 18, pp, 1-6. Quoted by Cooper, D. C. 1935 Macrosporom genesis and embryology of Medicago. Jour. Agr. Res. vol. 51, pp. 471-477.

Shattuck, C. H. 1905 A morphologleal study of glmus amerleana. Bot. Gaz. vol. 40, pp, 209m 223. Quoted by Walker, R. I. 1938 Macrosporogens is and embryo devolopment in Ulmus fulva. Bot. Gaz. vol. 99, pp. 592-598.

Small, J. 1919 The origin and development of the Compositee XII. Hew Phytol. vol. 18. pp. 129-176. Quoted by Cooper, G. 0 . 1938 Cytological investigations of Plsum sativum. Bot. Qaz. vol. 99, pp. 584-591. 
Stenar, H. 1927 Uber die Entwleklung dea alebenkornigen Embryosackes bel Gagea luten Ker. nebst olnigen Bemerkungen uber d1e Reduktionstellung bei Gagea minima Ker. Svensk Bot. T1dskr. 21: 344-360. Quoted by Walker, R. I. 1938 Macrom sporogenesis and embryo development in Ulmus fulva. Bot. Gaz. vol. 99, pp. 592-598.

Strasburger, E. 1880 Elnege Demerikungen uber vielkemige Zelion und uber die Embryegente von Lupinus. Bot. Ze1tschr. 38: 845854 857-868. Quoted by Andersen, A. u. 1927 Development of the fomale gamotophyte and caryopsis of Poe pratensie and Poa comprossa. Jowr. Agr. Res. vol. 34 , pp. 1001-1018.

Walker, R. I. 1938 Macrosporogenes is and embryo development in glmus fulve. Bot. Gsz. vol. 99 , pp. 592-598.

Weintein, A. J. 1926 Cytological studies of Phaseolus vulgarls. Amer. Jour. Bot. vol. 13, pp. 248-263. Quoted by Cooper, 
D. C. 1933 Mecrosporogenesis and embryology of Mel1lotus. Bot. Gaz. vol. 95, pp. 143-155.

Young, W. J. 1905 The embryology of Melllotus alba. Proc. Indiane Aced. Se1. pp. 133-144. Quoted by Reeves, R. G. 1930 Development of ovule and ombryo sac of alfalfa. Amer. Jour. Bot. vol. 17, pp. 239-246.

zirkle, C. 1930 The use of n-butyl alcohol in dehydrating woody tissue for paraffin embedalng. Sclence vol. 71, pp. 103-104. 
C HA P T R VIII 
PLATES

Key to Plates

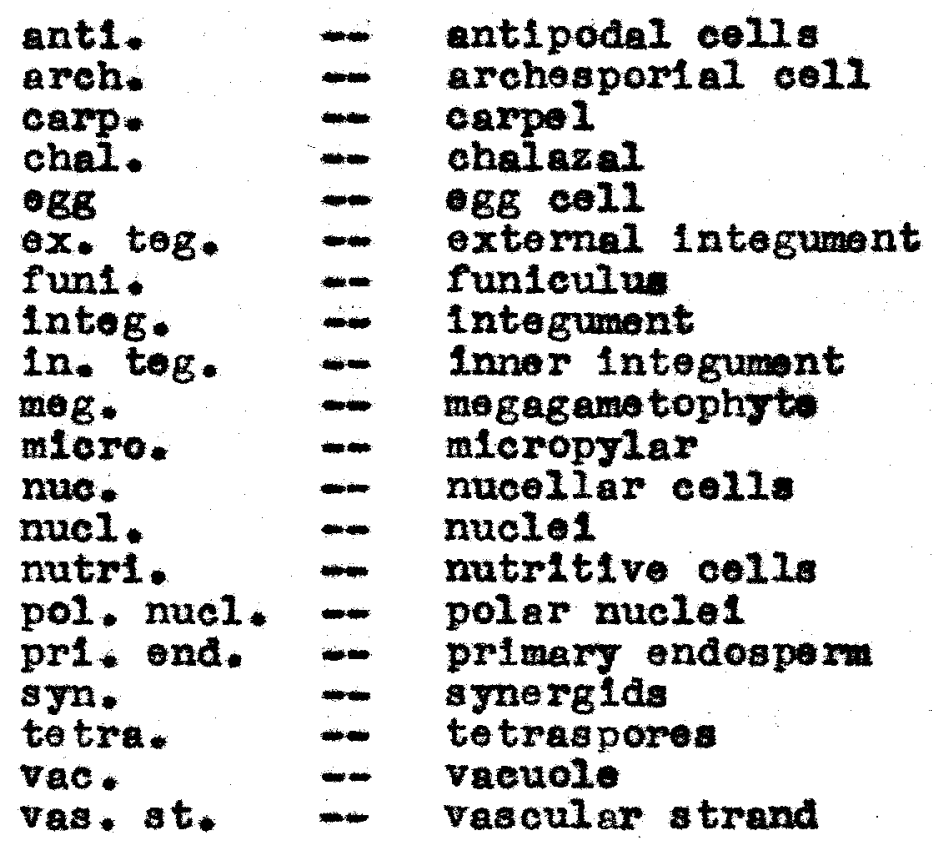


PLATE I

Early Developent of the Ovule 
PIATE I

Camera-lucla drawing of an early

stage in the development of the ovule in a

bad $2.61 \mathrm{~mm}$. In length, (collected May 26)

showing the formation of a roundea pro-

tuberance of undifferentiated nucellar cella

In the cavity of the ovary. More rapld

development eppeers on one side of the young

ovulo. 1530 diameters. 


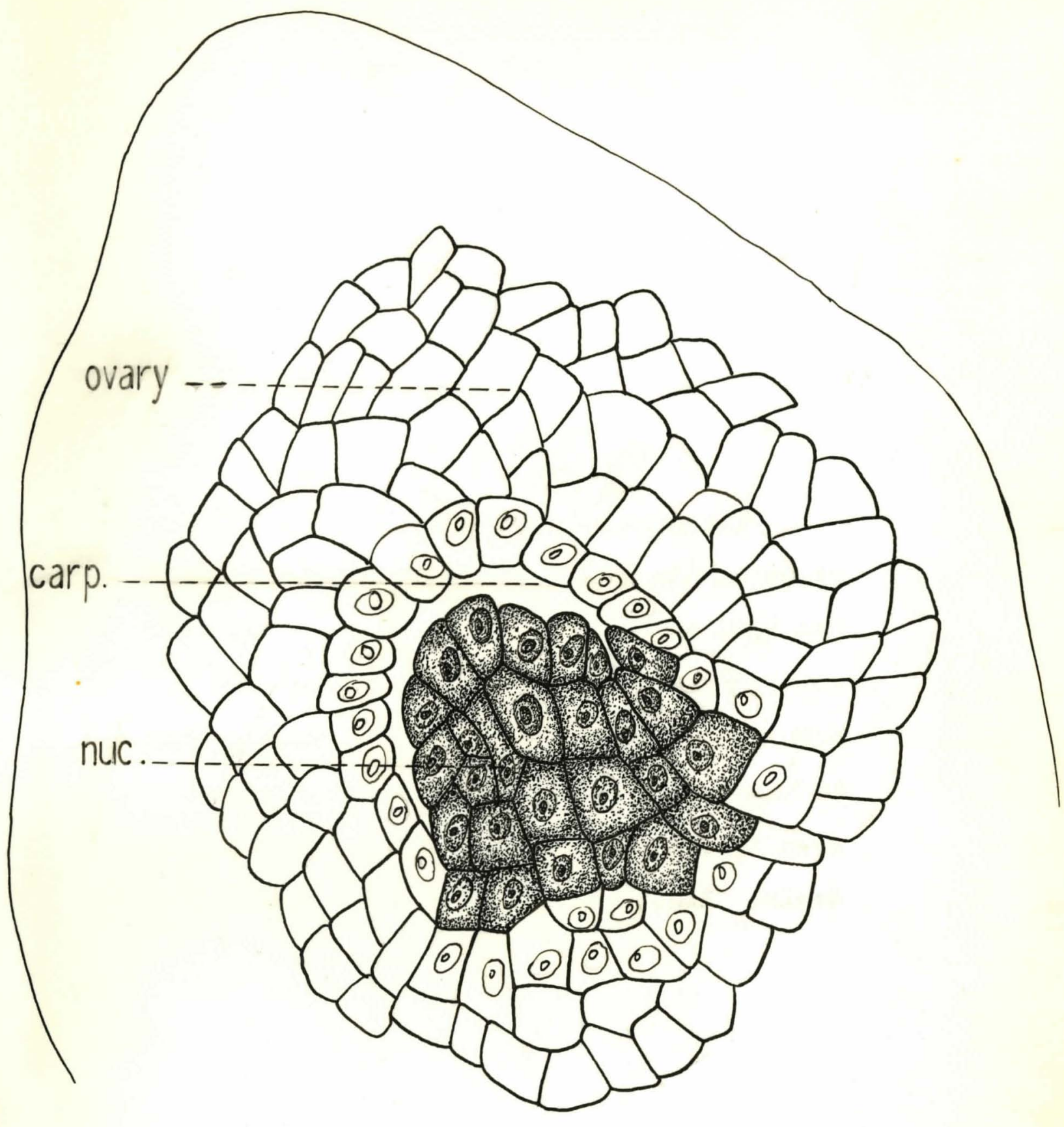

PLATE I. 
50

PLATE II

Undifferentiated Arohosporial $\cos 11$

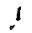


Camera-lue ida drawing of 1 ongl tudinal section of the ovary in a bu 2.6 m. long. (collocted May 26) showing an allgnment of the undiffexentlated collo of the developins ovalo. Ho archesportal oell can be alstinguished at this stage of development. 1525 di ane ters. 


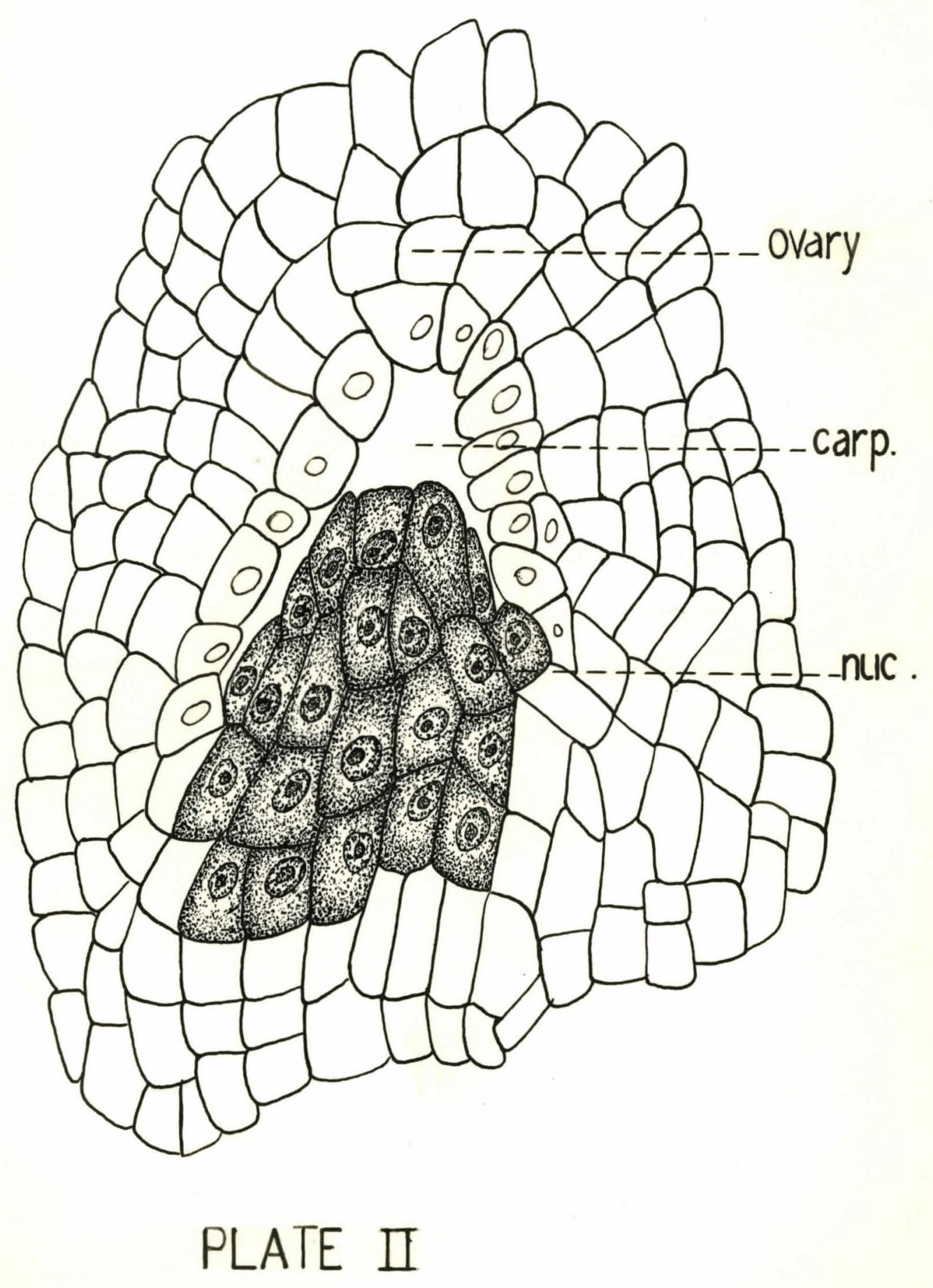


PIATE III

Rarly Development of the Integument 


\section{PLATE III}

Camera-lucida draving of longltudinal

section of the developing ovule of a bud

$2.81 \mathrm{~mm}$. Iong, (collected May 28) showing the organisation of cells of the nueellua about the archesporial cell. This cell which is deeply ombeddod in the nucollus is difficult to diatingulsh until after it has divided. The two leyers of the inner integument are beginning to form. 1102 dimeters. 


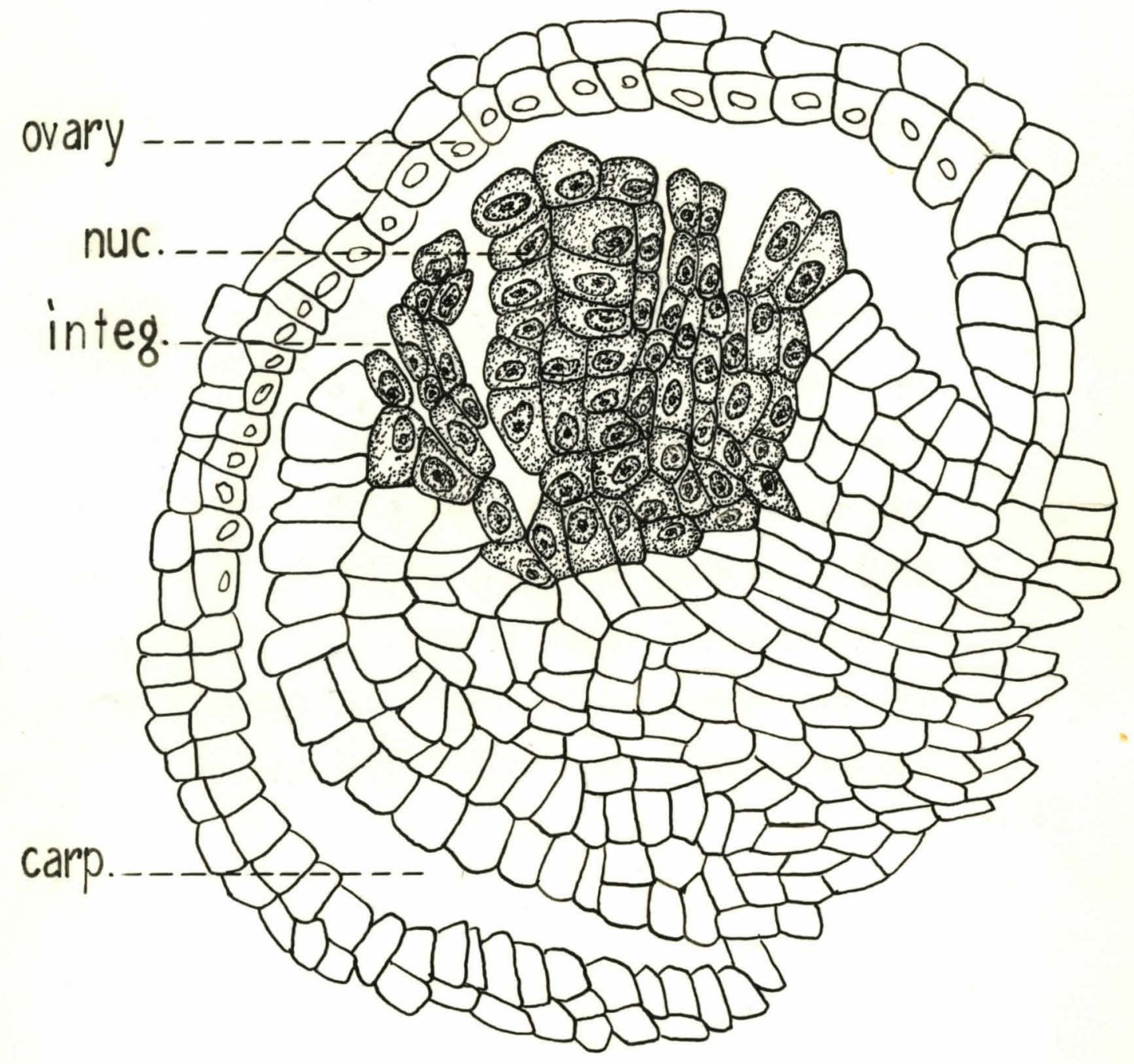

PLATE III 
PLATE IV

Formation of a Totrad of Mogasporea 


\section{PLATE IV}

Camera-luclda drawing of a linear row of four megaspores. The four megaspores In the ovule of a flower $4.24 \mathrm{~mm}$. Iong (collected June 2) are the result of two suocessive divisions of the archesporial cell. The tetrad shows an Inerese in the size of the chalazal functional spore of the tetrad and an incresse in the size of 1 ts nucleus before it divides. The tetrad is dooply ombedded in the nucollus and the inner integument has developed to a level even with the apex of the nueollus. The inner integument of two layers, excopt at the base whore it has three layers of cells growe upward about the apex of the nucellus. An outer integument of three layers of colls develope more rapldiy on the side away from the plecenta. 750 diameters. 


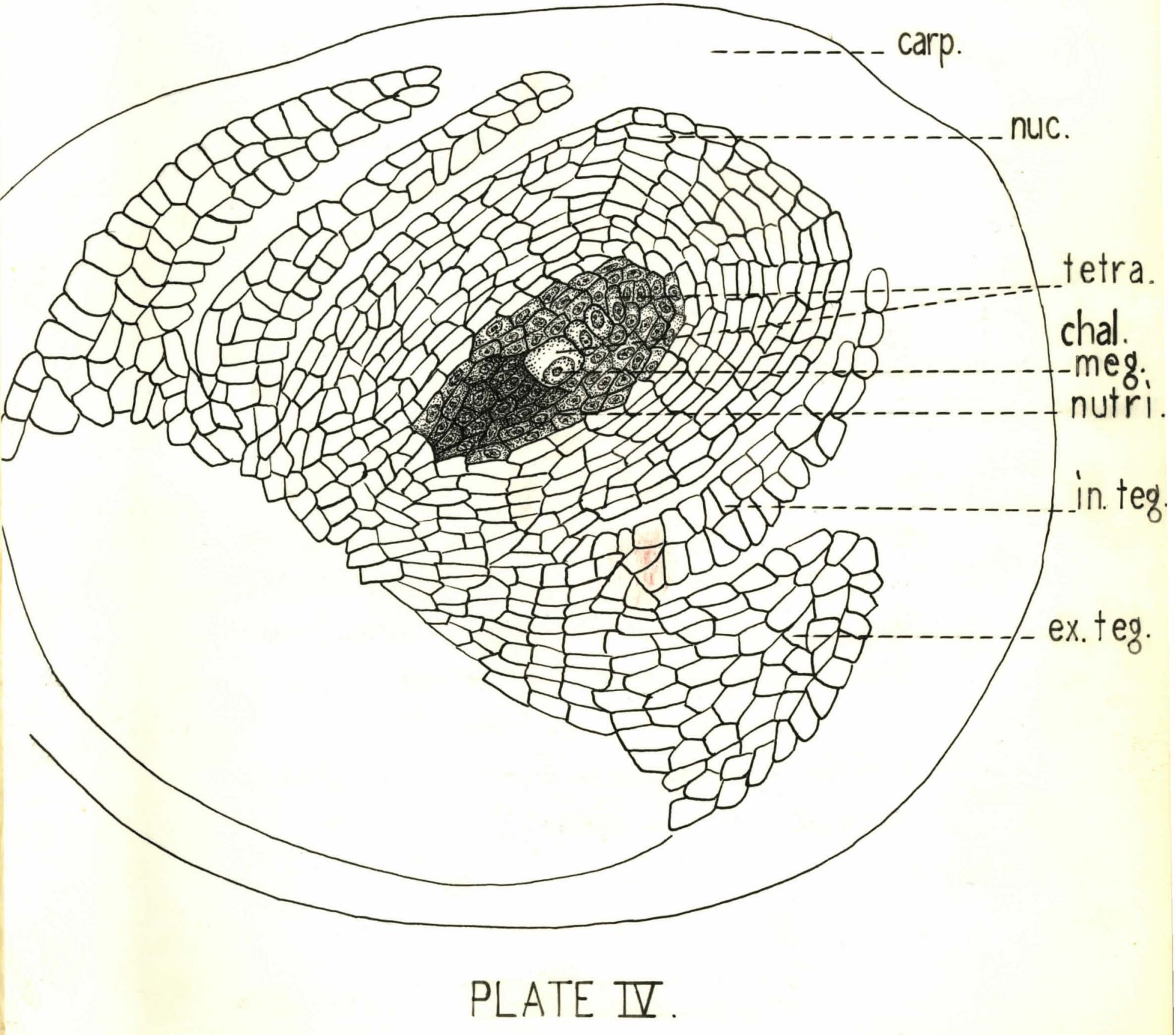




\section{PLATE V}

Longltudinal section of an Entire Ovary 


\section{PLATE V}

Came ra-lucida drawing of longltudinal

section through the ovary of a flower 4.24 w. (collected June 2), showlng the anstropous orule, the erowth of the integument over the micropylar end of the ovule, and the deaply embedded megagametophyte. The main vasoular strand of the orary extends into the funiculus toward the chalazal ond of the mogagemetophyte. 485 dlameters. 


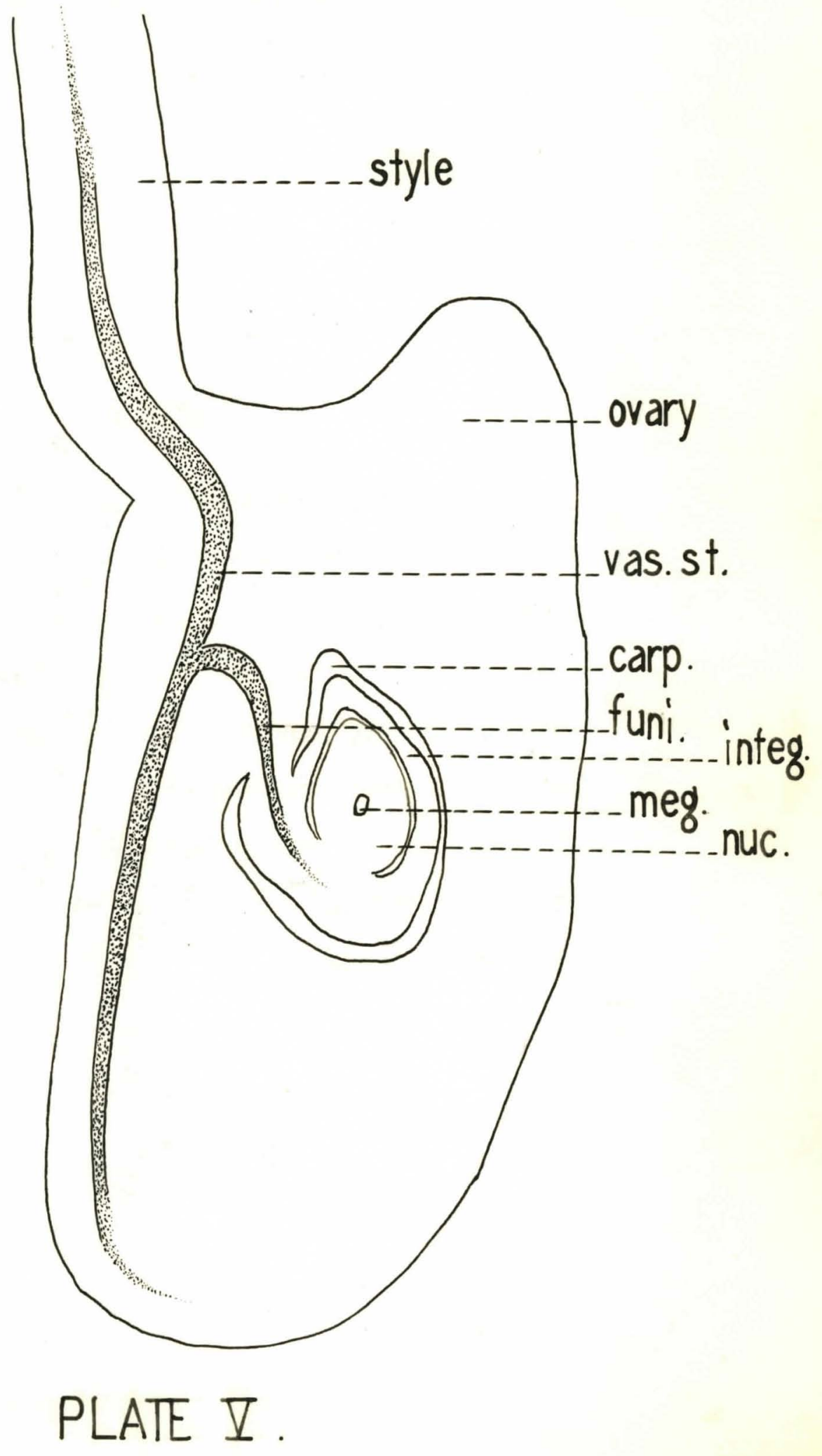




\section{PLATIR VI}

Development of the Chalazal Negaspore 


\section{PLATE VI}

Came ra-luelda drawing showing the development of the chalaral megaspore. In an ovule of a flower 4.24m. long (oollected June 2), the inear tetrad of megaspores shows great increase in size of the functional chalazal mogaspore and first division of Its nucleus. The three persisting megaspores at the micropylar ond disintegrate as the chalazal megaspore increases in sizo. A group of nutritive cells having dense cytoplasmie content are found about the chalazal end of the two-nueleate megagametophyte. 2000 diameters. 


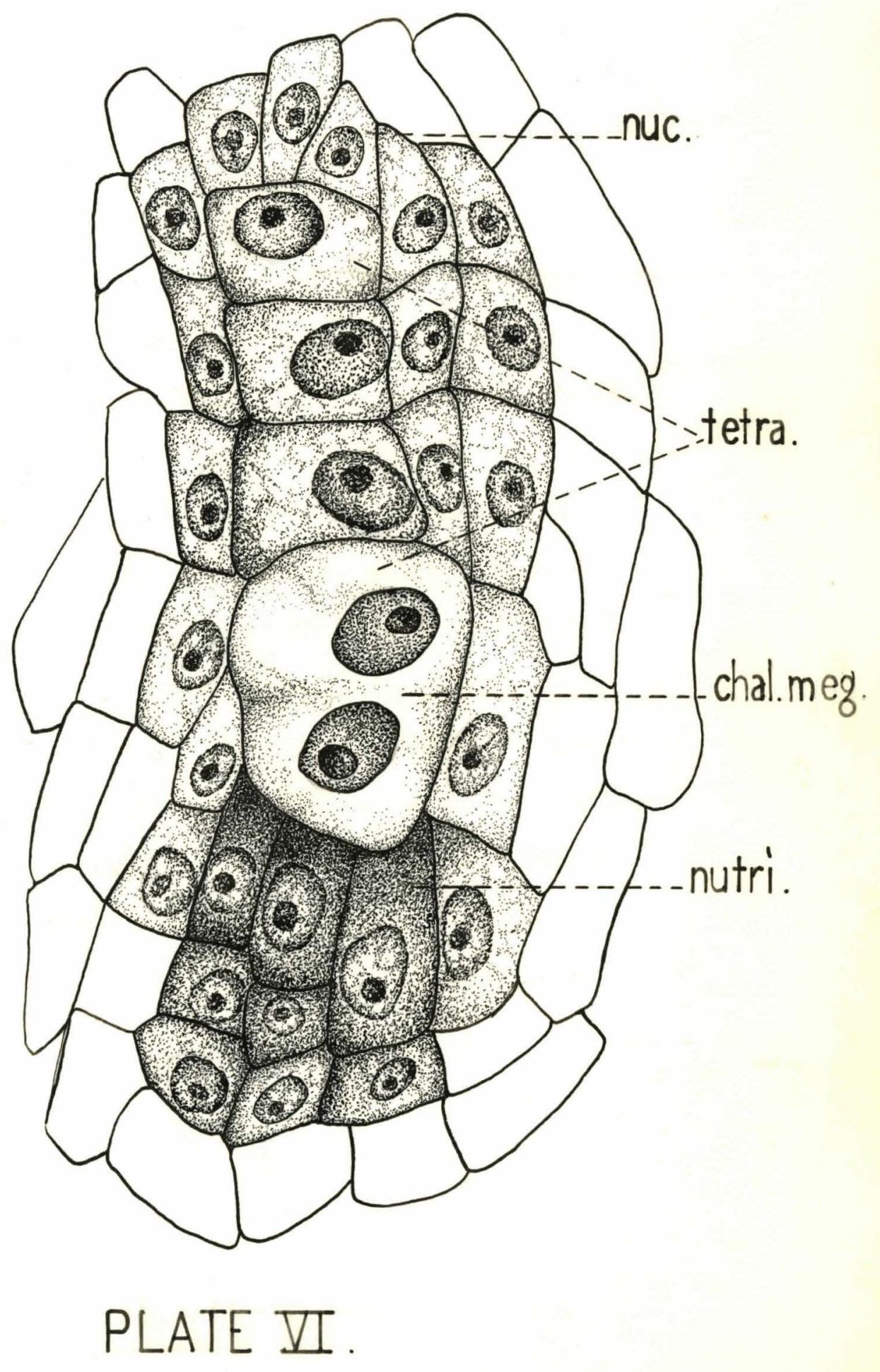


PLATE VII

Two-nucleate Embryo Sac 


\section{PLATE VII}

Camera-lucida drawing of two-nucleate embryo sac in an ovule of fruit 2.8 m. long (collected June 5). The two nuclel reaulting from the first mitotic diviaion of the nucleus of the funotional chalazal mogaapore migrate apart, one going to the mloropylar ond and the other toward the chalazal end. The diameter of the megagametophyto hes become greatly extended. A large vacuole forms in the mid-portion of the cell. 324 diame tera . 


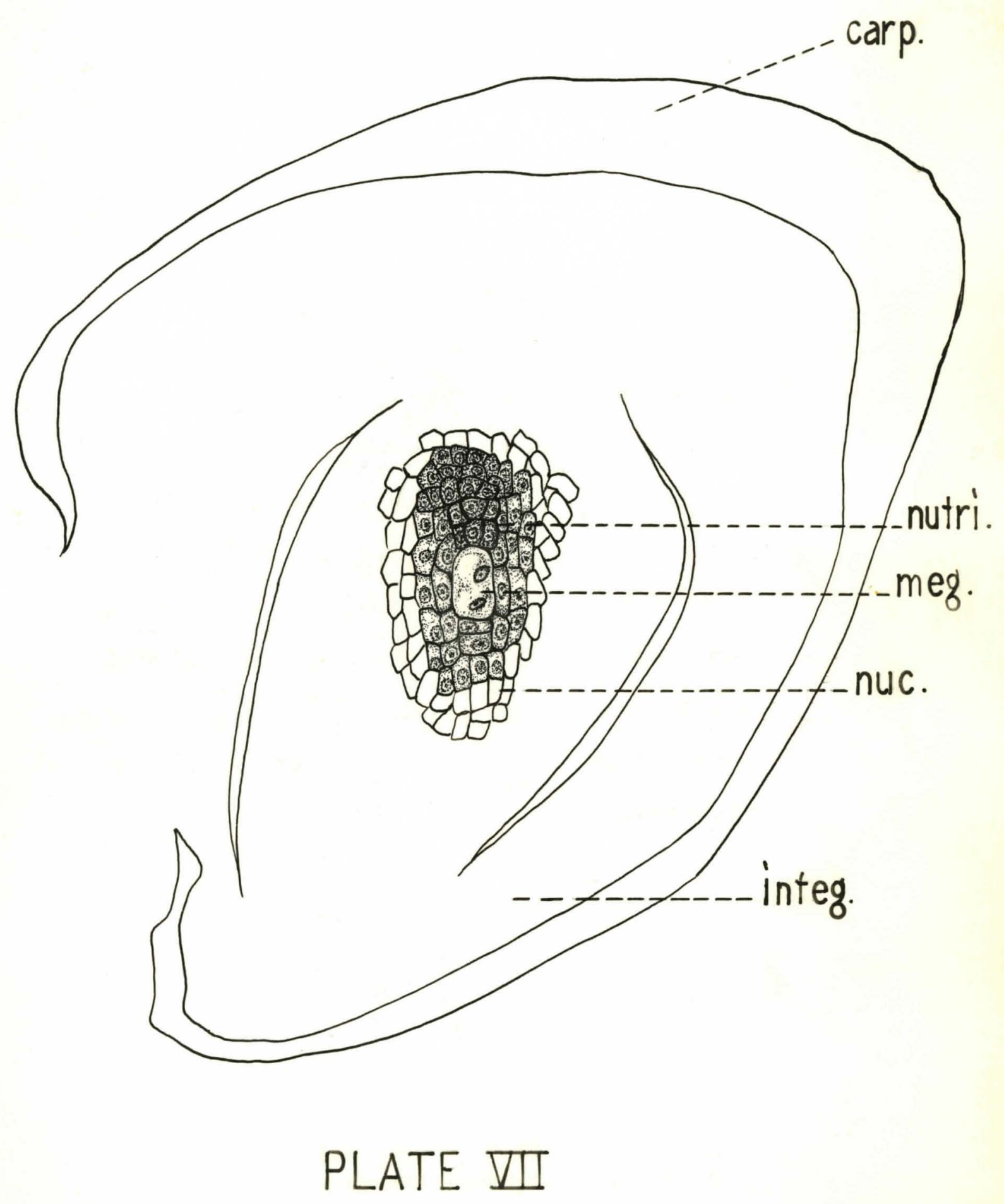




\section{PTATE VIII}

Two-nucleate Embryo sac 


\section{PLATE VIII}

Camera-lucida drawing of the enlargement of the two-nucleate megagametophyte shown in PLATE VII. The two nucle1 misrate apart and 110 in peripheral layer of oytoplasm, one in the meropylar and and the other in the chalazal and of the embryo sac. A vacuole exista in the ald-portion of the cell. Deeply stained nutrit1ve cells are found at the chalazal and of the embryo sac. The cells of the nucellus adjacent to the embryo sac have become flattened, elongated with the loss of nucle1, and show signs of belng absorbed by tho embryo sac. 2352 diameters. 


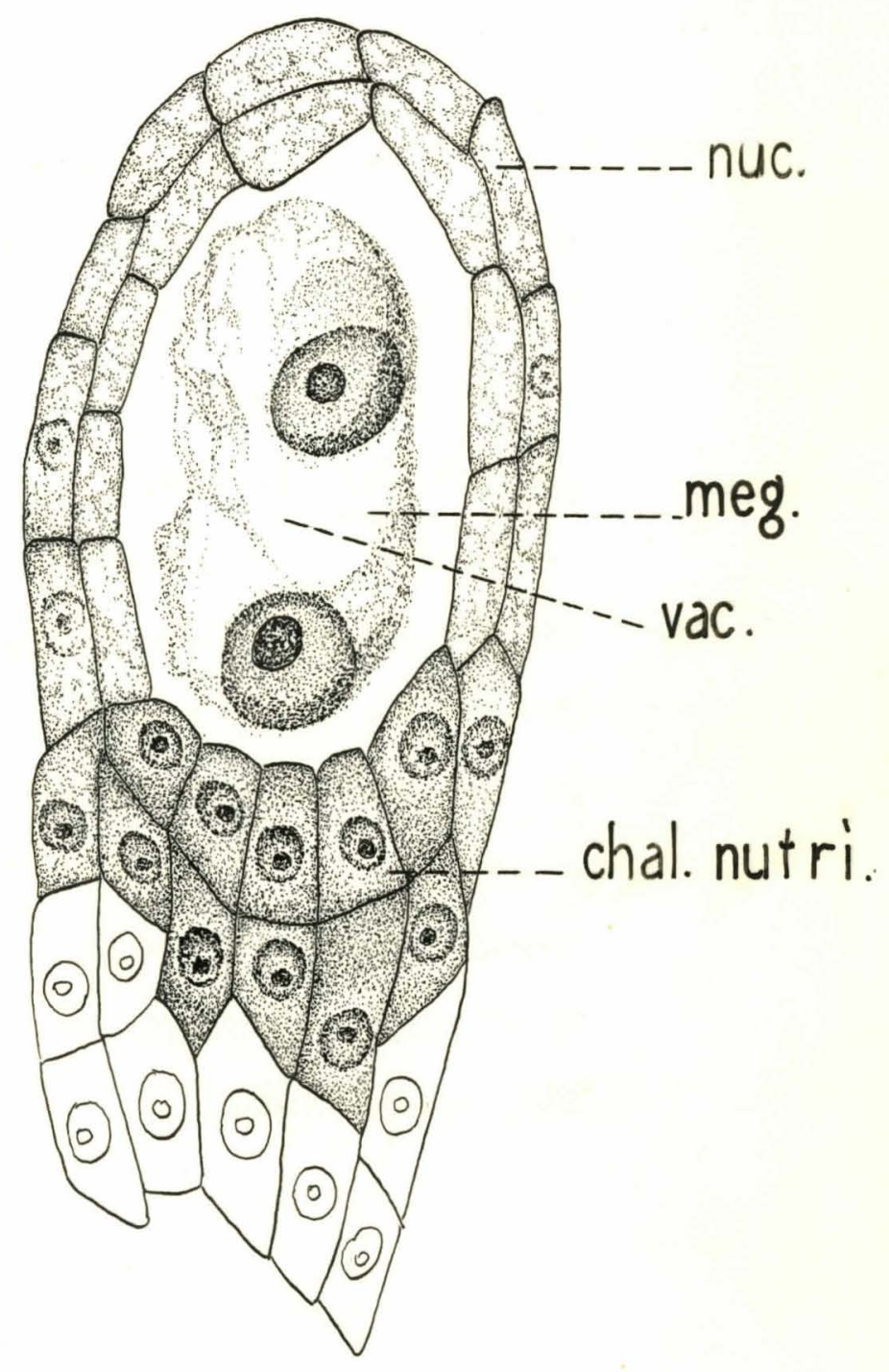

PLATE VIII 
PLATE IX

E1ght-nucleate Mogagane tophyto stage 
PLATE IX

Camera-lucida arating of an ovule of a frut $2.8 \mathrm{~mm}$. long (collected Juno 5) ahowing the mieropylar region in the elght-nucleate ambryo sac stage. The four nuclel which 110 in the peripheral layer of cytoplasm in the microm pylar region of the embxyo sac are the result of the mitotic division of the two daughter nuclel in the mieropylar region. One of these, the polar nuclous 1 grates toward the conter of the embryo sac. The ambryo sac shos a greater increase in diameter in the mleropylar region. 1602 diameters. 


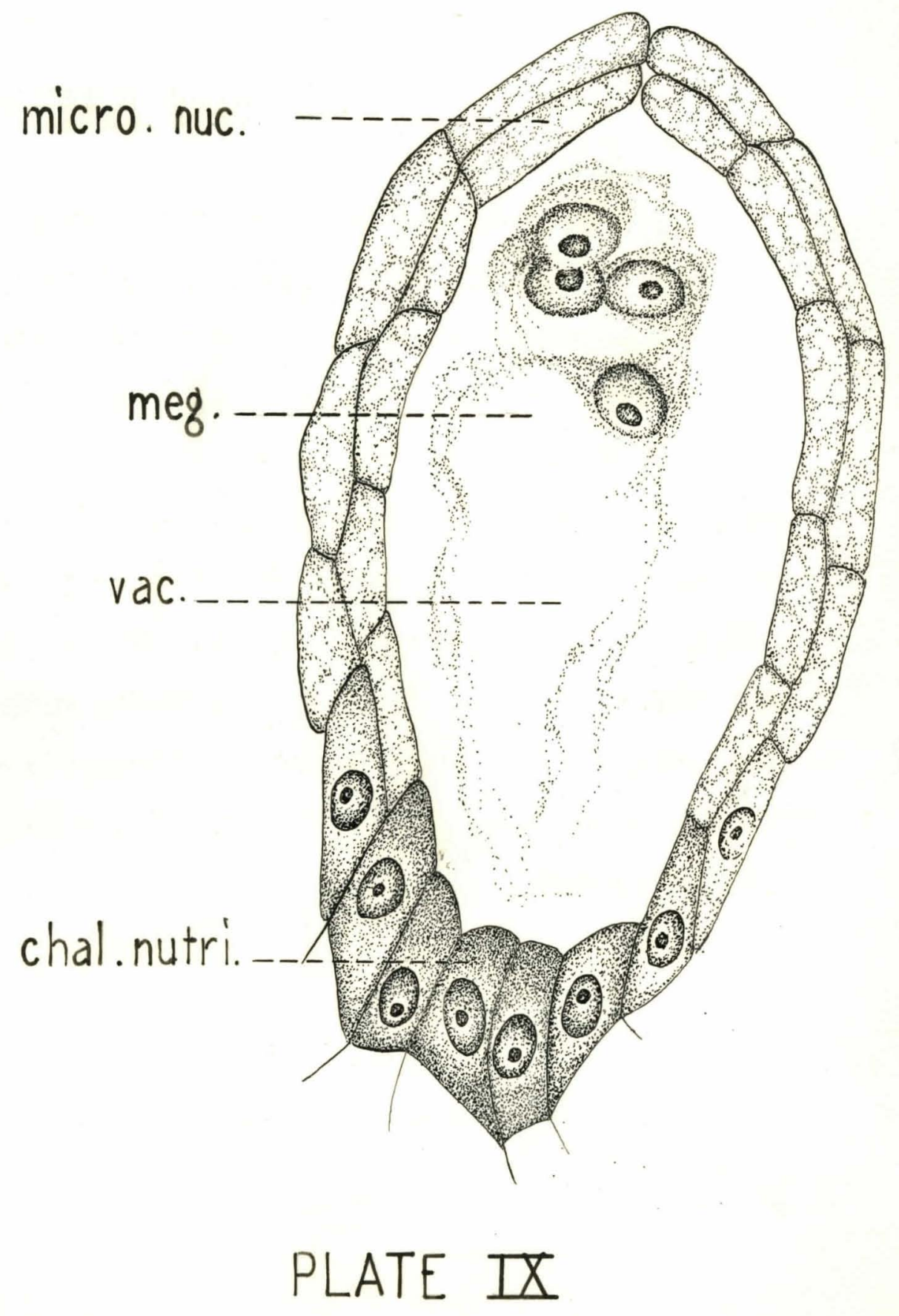


PLATE $x$

Mature Megegame tophy to 


\section{PLATR X}

Camera-luclda drawing of a longltudinal section through an ovule with a seven-celled eight-nucleate embryo $\mathrm{sac}$, in a fruit $4.6 \mathrm{~m}$. (collected June 8). The ege apparatus in the micropylar ond consists of the egg coll and two synergids. The micropylar ends of the synerglds elongate and extend toward the micropyle. The two polar nuclel devold of limlting membrano ile in contact with one onother in the center of the embryo sac and form a two-nucleate endosperm ce11. Three uninucleate entipodel cells are found in the chalazal ond of the embryo sac whioh la still deeply embedded in the nucollus. 439 diameters. 


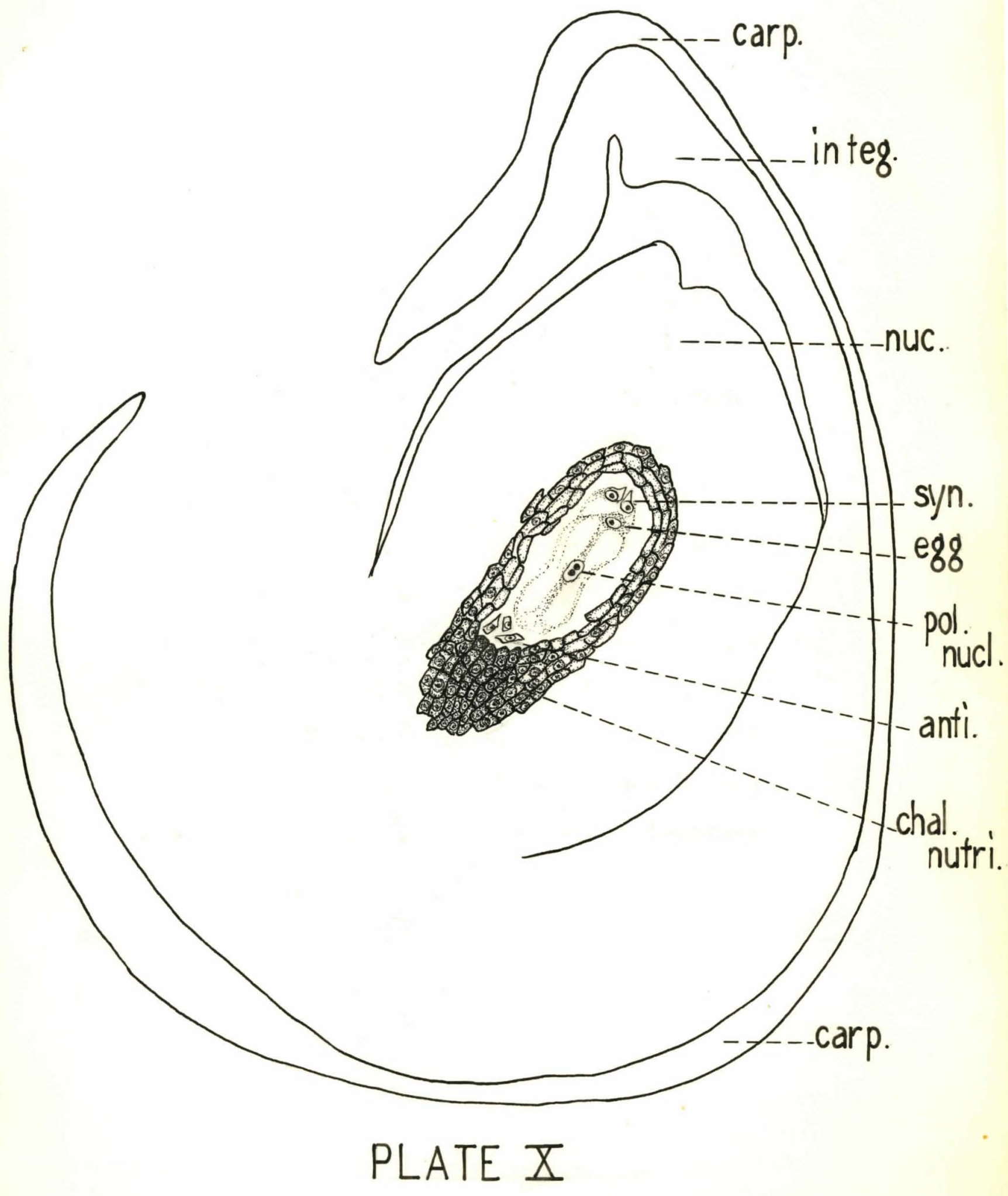




\section{PLATE XI}

Bnlargement of Uature Vegagametophyte 


\section{PLATE XI}

Came ra-luelda drawing of an onlargement of the mature mogagametophyte shown in PLATE $X$. The eight-nueleate mature megagametophyto consists of throe uninucleate antipodals separated from the renainder of the embryo sac, twonucleate endospera cell in the center, a large Ogg nucleve and two symergids with smaller nuele1 in the micropylar region. 2588 diameters. 


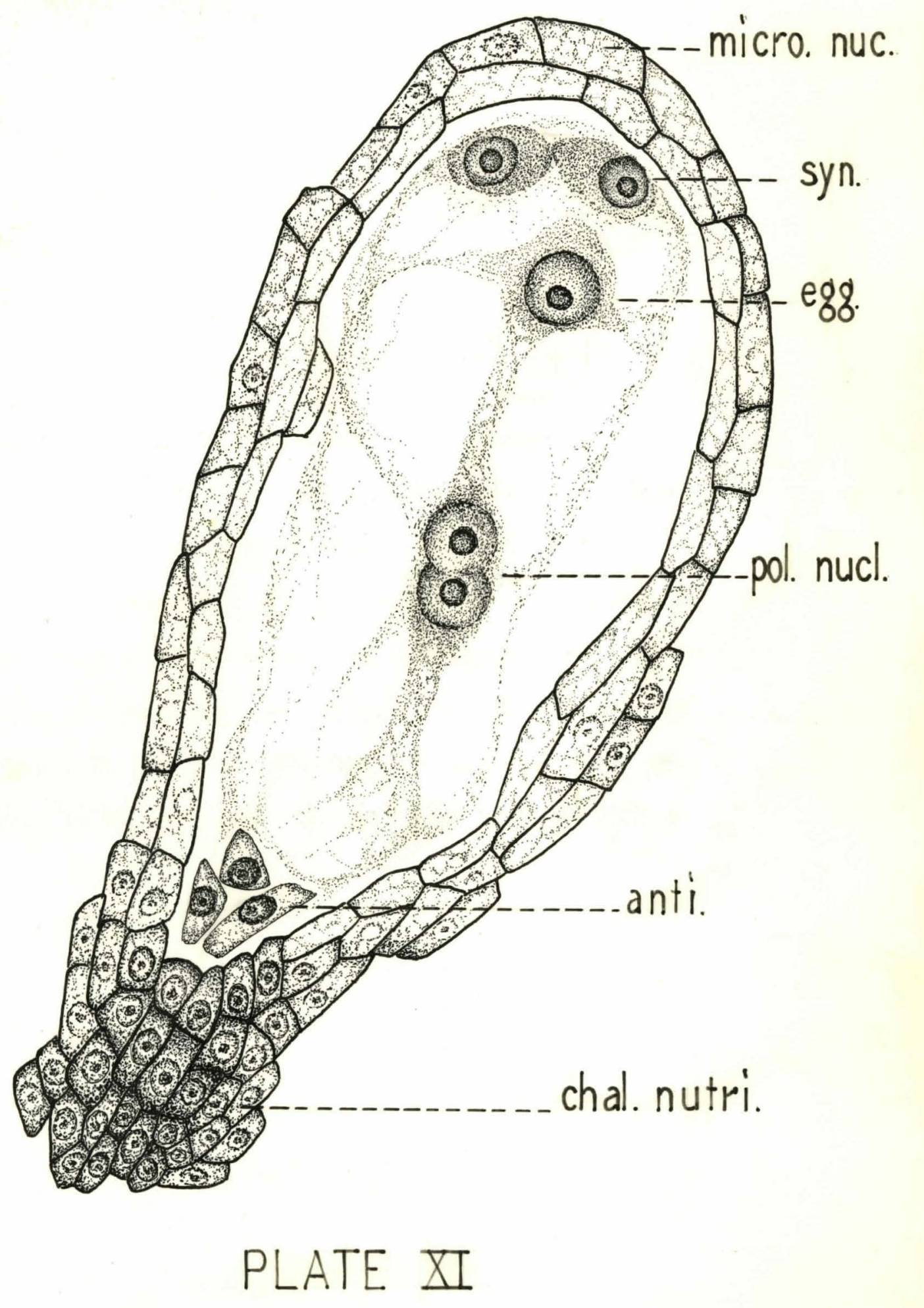




\section{PLATE XII}

Formetion of the Primary Endoapern Cell 
PLATE XII

Camera-luelda arawing of embryo sac of ovule of a fruit $4.6 \mathrm{~mm}$. long (collected June 8) showing the primary ondoaporn cell. The two poler muclel have fused after cell formation. The synergids have beacme aeparated from the remainder of the embryo sac and are in stages of disintegration. The antipodals persist at this stage of development. 1838 dlameters. 


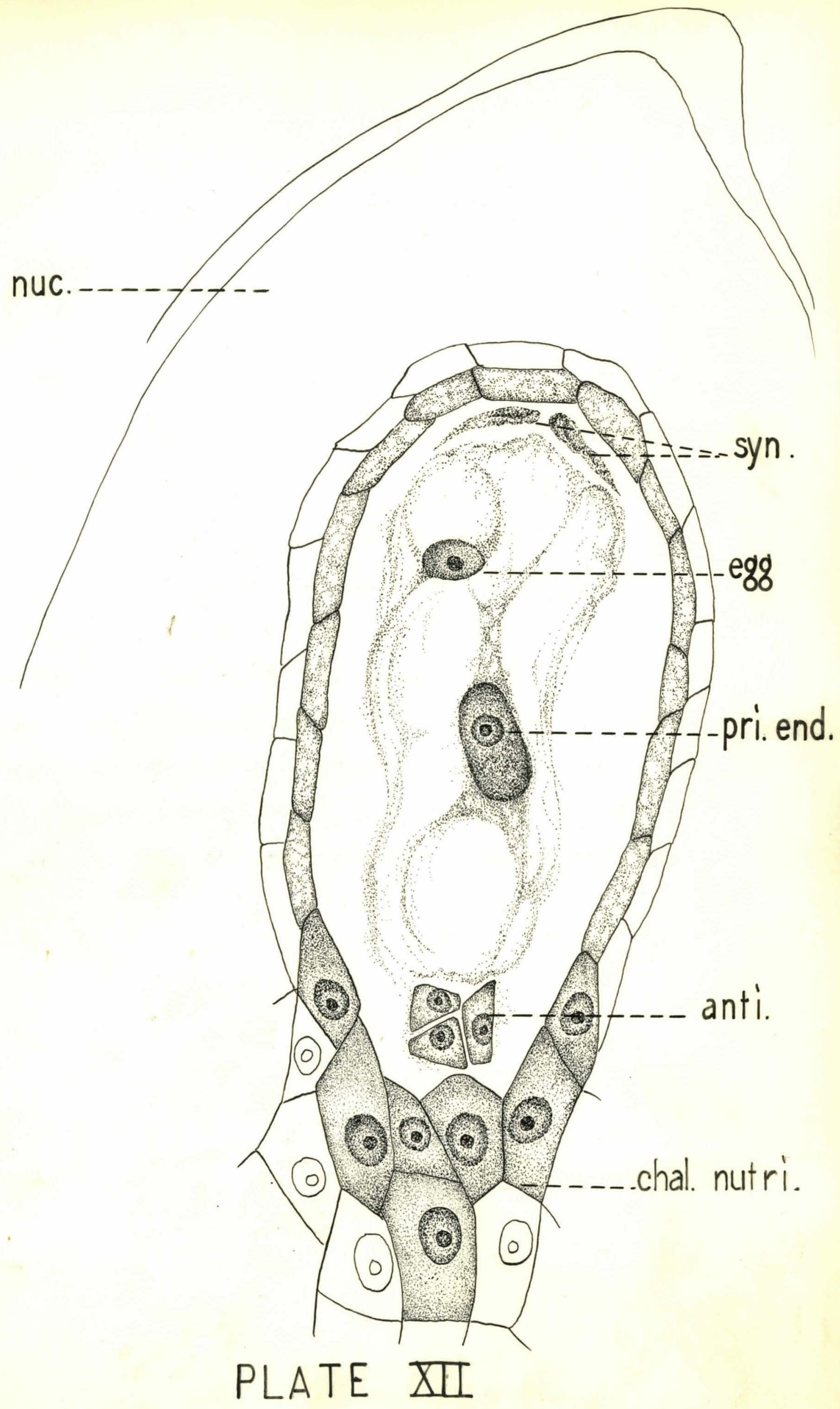

